\title{
Düzce Kent Merkezi Zeminlerinin Sıvılaşma Potansiyelinin Değerlendirilmesi
}

\author{
Evaluation of Liquefaction Potential of Soils in Düzce City Center \\ Müge K. AKIN Di ; \\ Abdullah Gül Üniversitesi, Mühendislik Fakültesi, Inşaat Mühendisliği Bölümü, \\ Sümer Kampüs, 38080 Kayseri
}

ÖZ

Zemin sıvılaşması depremler sırasında suya doygun bazı zeminlerde meydana gelen ve önemli düzeyde yüzey deformasyonlarına neden bir olaydır. Temel zeminin taşıma gücünü yitirmesi sebebiyle yapılarda oturma ve devrilme gibi önemli hasarlara yol açabilmektedir. Düzce ve yakın çevresi yeraltısuyu seviyesinin oldukça yüzeye yakın olduğu ve çoğunlukla siltli ve kumlu birimlerden oluşan düz bir ova üzerinde kurulmuştur. Bununla birlikte, Düzce ve yakın çevresi için Kuzey Anadolu Fay Zonu büyük depremler üretebilecek önemli bir sismik kaynaktır. Bu özellikler dikkate alındığında, olası büyük bir depremde Düzce ve yakın çevresinde sıvılaşma ve sıvılaşmaya bağlı yanal yayılma türü yüzey deformasyonlarının meydana gelebileceği olasıdır. Bu çalışmada, Düzce'deki yerel zemin koşullarının ve yeraltısuyu durumunun belirlenmesi amacıyla yapılmış 40 adet jeoteknik sondaja ait veriden yararlanılmıştır. Arazi çalışmaları sonucu yeraltısuyu seviyesinin sığ ve zemin türünün de gevşek alüvyon olduğunun belirlenmesi nedeniyle Düzce kentinin sıvılaşma potansiyelinin değerlendirilmesi amaçlanmıştır. Sıvılaşma Potansiyeli İndeksi (LPI) yöntemi ile Sıvılaşma Şiddeti İndeksi (LSI) yöntemleri esas alınarak Düzce ili için sıvılaşma potansiyeli değerlendirilmiş ve farklı deprem senaryolarına göre CBS ortamında her iki yönteme göre sıvılaşma potansiyeli haritaları hazırlanarak karşılaştırılmıştır. Çalışma kapsamında ön değerlendirmeye yönelik hazırlanan sıvılaşma haritalarına göre yeni yapılaşmaların arttığı inceleme alanının güney ve güneydoğu kesimlerinde sıvılaşma potansiyelinin yüksek-çok yüksek olduğu gözlenmektedir.

Anahtar Kelimeler: Sıvılaşma, Düzce, Sıvılaşma Potansiyeli İndeksi, Sıvılaşma Şiddeti İndeksi, Kuzey Anadolu Fay Zonu, Deprem

\begin{abstract}
Soil liquefaction is one of the ground deformations occurred during an earthquake which may cause serious damages such as settlement and tilting of structures due to loss of bearing capacity of foundations. Düzce and its surrounding settle on a plain which consists of silty and sandy layers with shallow groundwater level. Besides, the North Anatolian Fault Zone is a major seismic source which is capable of producing large magnitude earthquakes. All these data point out that the ground deformations like liquefaction and lateral spreading may occur during a probable large earthquake around Düzce and its close vicinity. In this study, the geotechnical data of 40 boreholes drilled to determine the local ground conditions and the groundwater level in Düzce were considered. Based on the field studies, it was aimed to evaluate the liquefaction potential considering the fact that the groundwater level
\end{abstract}


Akın

is shallow as well as the subsurface soil is composed of loose alluvium. Liquefaction Potential Index (LPI) and Liquefaction Severity Index (LSI) methods were taken into account and the liquefaction potential of Düzce province was determined and mapped with respect to various earthquake scenarios in GIS environment. These maps are compared on the basis of different scenarios. Accordingly, it is concluded that the liquefaction potential is high-very high in the south and south-eastern sections of the study area where the construction of new residential buildings progressively continues.

Keywords: Liquefaction, Düzce, Liquefaction Potential Index, Liquefaction Severity Index, North Anatolian Fault Zone, Earthquake

\section{GíRiș}

Zemin sıvılaşması, deprem sırasında artan boşluk suyu basıç̧larına bağlı olarak efektif gerilmenin ortadan kalkmasıyla özellikle kumlu zeminlerin siv1 gibi davranmas1 sonucu meydana gelir. Bu olay, aynı zamanda gevşek, doygun kumlarda sıkılığın ve dayanımın geçici olarak yitirilmesine neden olur. Yakın geçmişte de birçok örnekte yaşandığ 1 gibi, 1999 Kocaeli depreminde Adapazarı'nda, sıvılaşmaya bağlı olarak ciddi hasarlar oluşmuştur. Sıvılaşma tanımı ilk olarak 1930'ların sonlarında Casagrande tarafından ortaya atılmıştır (Day, 2002). 19. yüzyılın ortalarına doğru sıvılaşma ve etkileri sıvılaşmaya bağlı etkilerin oldukça belirgin olarak gözlendiği iki önemli deprem sonrasında birçok araştırmacı tarafından çalışılmıştır. $\mathrm{Bu}$ depremler, 1964 y1lındaki Alaska ve yine 1964 y1lı içinde meydana gelen Niigata depremleridir. Her iki deprem de sıvılaşma açısından oldukça önemli veriler sunmuşlardır (Kramer, 1996). Daha yakın zamandaki 1995 Kobe ve 1999 Kocaeli depremlerinde de birçok yapı sıvılaşma ve sıvılaşma sonrası etkilere maruz kalmıştır.

Özellikle yapılaşmaya yönelik değerlendirmelerin yapıldığı alanlarda olası sıvılaşma etkileri senaryo depremler ve yerel zemin koşulları dikkate alınarak belirlenmelidir. Bir bölgedeki zeminin sıvılaşma potansiyelinin belirlenmesine yönelik birçok yöntemönerilmiştir (Seed ve Idriss, 1971; 1982; Seed vd., 1985;
2001; Poulos vd., 1985; NCEER, 1997; Youd ve Noble, 1997; Youd vd., 2001; Kramer, 1996; Çetin, 2000; Çetin vd., 2004; Idriss ve Boulanger, 2006; Akin vd., 2013). Zeminin sıvılaşmaya karşı direcinin (dayanımının) belirlenmesinde zemin profili boyunca Standart Penetrasyon Testi (SPT), Konik Penatrasyon Testi (CPT) veya Makaslama dalagası hızı $\left(\mathrm{V}_{\mathrm{s}}\right)$ ölçümleri dikkate alınmaktadır. SPT; pratik ve ucuz bir deney olması bakımından en yoğun tercih edilen yöntemdir. Ayrıca mühendislik uygulamalarında da, yaygın kullanıma bağlı olarak SPT deneyleri konusunda oldukça fazla tecrübe edinilmiştir. Bununla birlikte, CPT'ye (Robertson ve Wride, 1998; Toprak vd., 1999; Juang vd., 2003; Olsen, 1984; 1997; Moss, 2003; Moss vd., 2006) ve $\mathrm{V}_{\mathrm{s}}$ 'e (Andrus ve Stokoe, 1997; 2000) dayal1 yöntemler de oldukça önemli avantajlara sahip olup, son yıllarda yaygınlık kazanmaktadırlar.

$\mathrm{Bu}$ çalışmada jeoteknik sondajlar ve laboratuvar deney sonuçları dikkate alınarak Düzce kent merkezi zeminleri için sıvilaşma potansiyeline yönelik ön değerlendirmeler yapılmıştır. Coğrafi bilgi sistemleri (CBS) tabanlı bir bilgisayar yazılımı olan ArcGIS 9.3 (ESRI, 2009) kullanılarak tüm veriler sıvılaşma potansiyelinin değerlendirilmesi amacıyla farklı senaryo durumları için Sıvılaşma Potansiyeli İndeksi (LPI) ve Sıvılaşma Şiddeti İndeksi (LSI) yöntemlerine göre düzenlenerek ilgili haritalar CBS ortamında üretilmiştir. 


\section{INCELEME ALANI}

Düzce $40^{\circ} 37^{\prime}$ ile $41^{\circ} 07^{\prime}$ kuzey enlemleri ve $30^{\circ} 49^{\prime}$ ile $31^{0} 50^{\prime}$ doğu boylamları arasında yer alan, $2.593 \mathrm{~km}^{2}$ genişliğinde bir Batı Karadeniz Bölgesi ilidir. Kapladığ 1 alan bakımından Türkiye yüzölçümünün $\left(783.577 \mathrm{~km}^{2}\right)$ binde 33'ü kadardır. Doğusunda Zonguldak ve Bolu, güneyinde yine Bolu, batısında ise Sakarya illeri ile komşudur (Şekil 1). Düzce ili Batı Karadeniz
Bölgesi'nde yer almakta olup, Türkiye İstatistik Kurumu (TÜİK)'nun Adrese Dayalı Nüfus Kayıt Sistemi verilerine göre 2016 yılı sonu itibarıla merkez nüfusu 162 bin 897 ve il geneli nüfusu ise 370 bin 371 olarak belirlenmiştir. Düzce'nin bilinen tarihi M.Ö. 1390 yıllarına kadar gitmektedir. Yöre, birçok kavimin ve devletin istilasına maruz kalmıştır. Çevrede Frig, Lidya, Pers, Roma, Bizans, Selçuk ve Osmanlı uygarlıklarının izlerini görmek mümkündür.

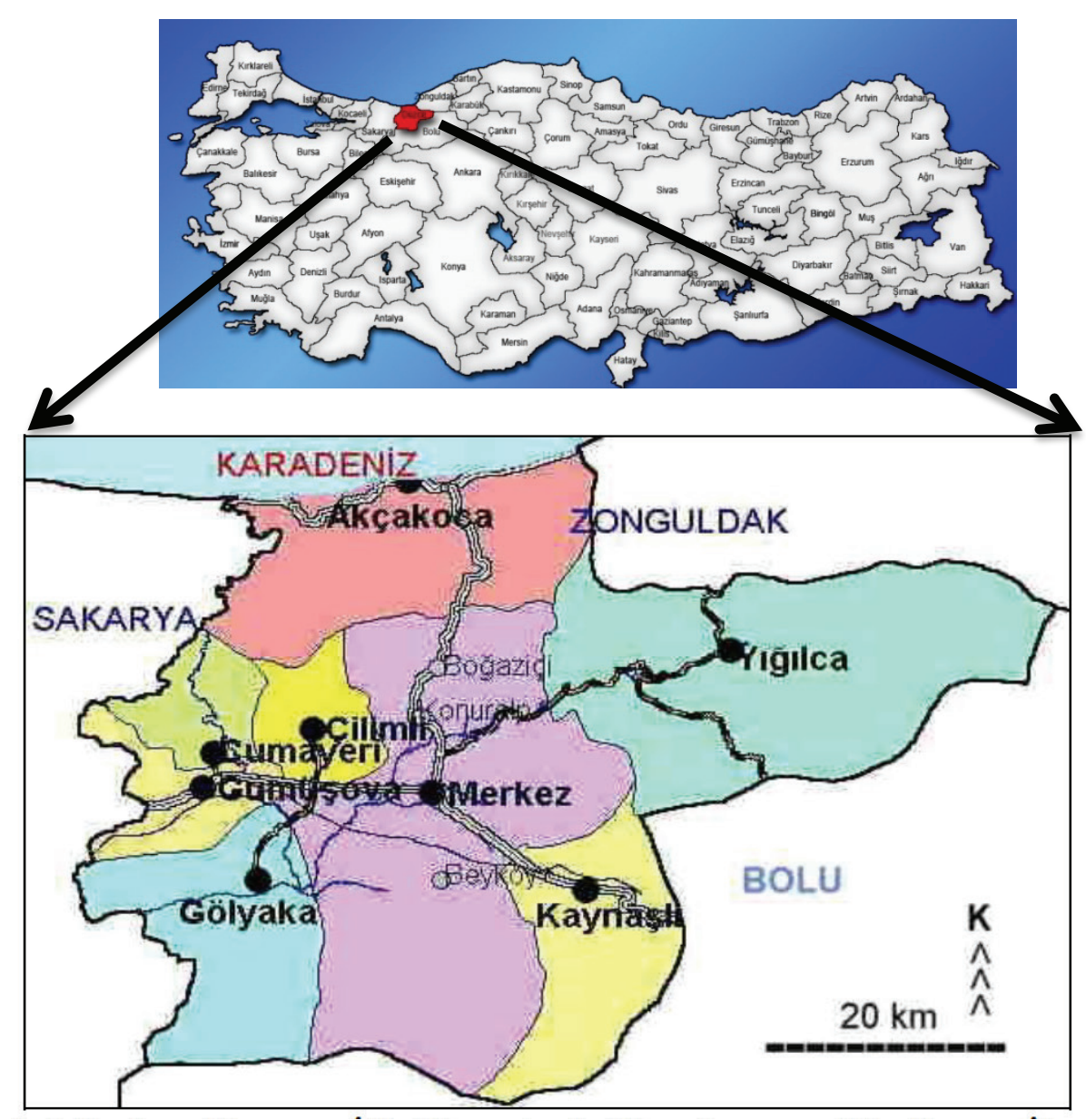

Şekil 1. Düzce yerleşim yeri haritası.

Figure 1. Location map of Duzce settlement. 
Akın

\section{INCELEME ALANI VE YAKIN ÇEVRESININ JEOLOJISI}

Düzce ve yakın civarındaki en yaşlı birim Düzce ovasının güney batısında Prekambriyen yaşl1 meta-granotoyitlerdir (PEy) (Şekil 2) (Şengör ve Y1lmaz, 1981). Düzce Fayı, bu birimler ile Kuvaterner çökelleri arasındaki sınırı oluşturur. Genç Çökeller (Qa); Düzce havzasını dolduran tümü kırıntılı çökellerin
(Geç Pleyistosen-Holosen), depolama yerine bakmaksızın çakıl-kum-silt ve killerden oluştuğu görülür (Y1lmaz vd., 1997). Havza kenarlarında çok az miktardaki döküntü veya yamaç molozunun dışında alüvyal ve gölsel alanlarda depolanmış oldukları dikkat çeker. Düzce havzasındaki sediment kalınlığının geçmiş sondaj bilgilerine ve jeofizik verilere dayalı olarak yaklaşı $260 \mathrm{~m}$ civarında olduğu tespit edilmiştir (Özmen, 2000).

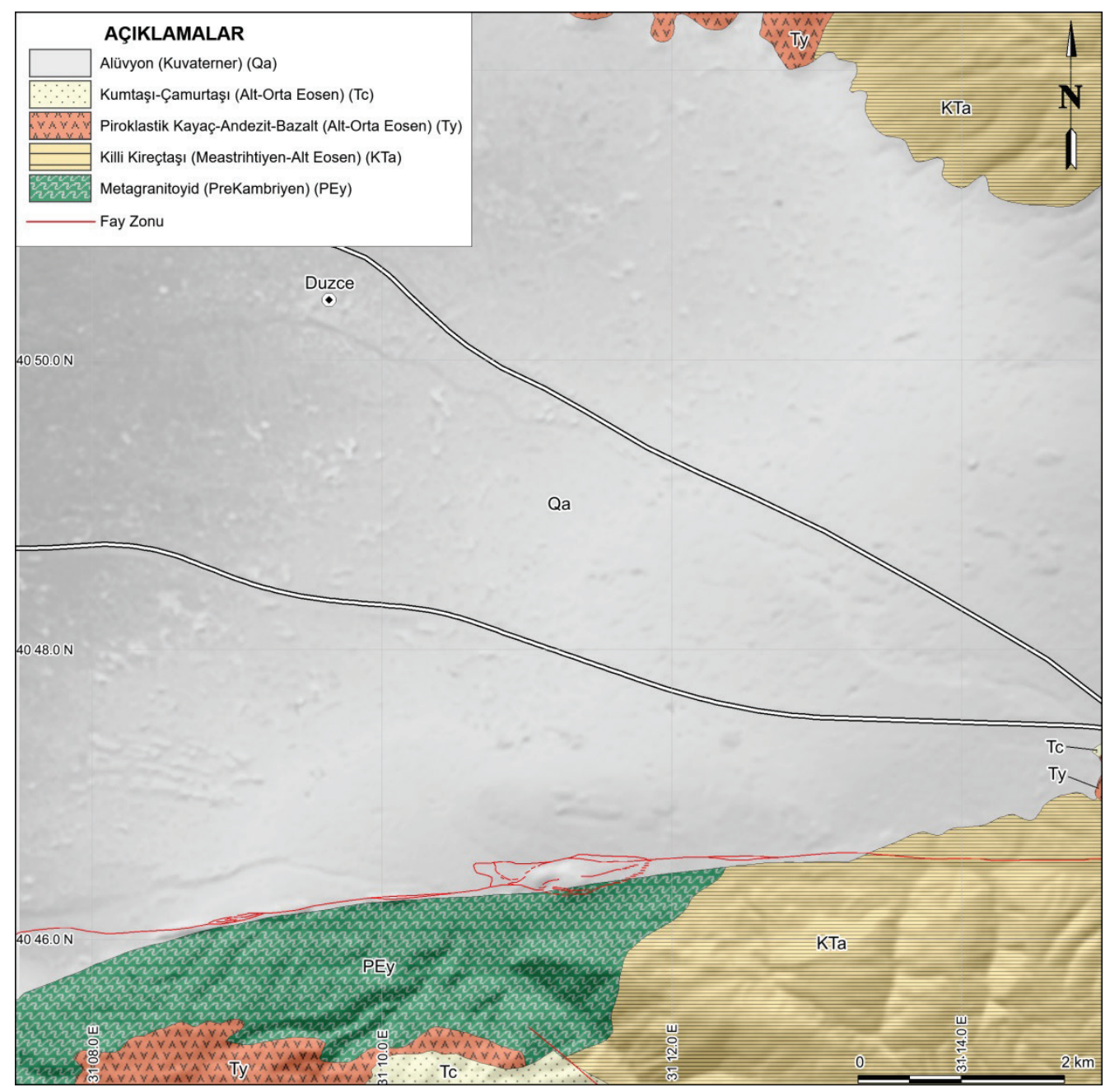

Şekil 2. Düzce ve civarının jeolojik haritası (Uysal ve Herece, 1999'dan alınmıştır).

Figure 2. Geological map of Duzce and its vicinity (modified after Uysal and Herece, 1999). 


\section{INCELEME ALANI VE YAKIN ÇEVRESINIIN DEPREMSELLİĞİ}

Düzce ili ve yakın çevresi 17 Ağustos ve 12 Kasım 1999 tarihlerinde yakın aralıklı meydana gelen iki büyük depremden büyük ölçüde etkilenmiştir. Her ikisi de Kuzey Anadolu Fay Zonu (KAFZ) üzerinde meydana gelen bu depremlerden ilkinin merkez üssü Gölcük olup, ikincisinin ise Düzce Dağdibi köyü olmuştur (Şekil 3 ve 4). Pek çok çalışmaya konu olan Gölcük depreminin aletsel büyüklüğü 7.4, odak derinliği $15.9 \mathrm{~km}$, süresi 45-50 saniye, en büyük yatay kayma yaklaşık $5 \mathrm{~m}$, toplam yüzey kırığı uzunluğu $140 \mathrm{~km}$ olarak verilmektedir (Emre vd., 1999). Düzce depreminin aletsel büyüklüğü ise 7.2 , odak derinliği $14 \mathrm{~km}$, en büyük yatay kayma yaklaşık $4 \mathrm{~m}$ ve toplam yüzey kırı̆̆ 1 uzunluğu 40 km olarak belirlenmiştir (Demirtaş vd., 2000). 12 Kasım 1999 Düzce depreminde kent merkezinde depremin oluşturduğu deprem moment büyüklüğü $\mathrm{M}_{\mathrm{w}}=7.2$ ve yatay deprem ivmesi değeri $0.52 \mathrm{~g}$ olarak kaydedilmiştir.

Kuzeyde Asya-Avrupa levhası ile güneyde Anadolu levhalarını birbirinden ayıran Kuzey Anadolu Fay Zonu (KAFZ), yaklaşık uzunluğu $1200 \mathrm{~km}$. olan doğrultu atımlı bir fay sistemi olup ülkemizin en önemli tektonik yapılarından biridir. Düzce havzası Kuzey Anadolu Fay Zonu (KAFZ) üzerinde bulunmaktadır (Şekil 3). Düzce havzasına en yakın konumlu olan ve deprem potansiyeli taşıyan faylar Düzce, Hendek ve Çilimli faylarıdır. Bu faylardan Düzce ve Hendek fayları aktif fay karakterindedir. Çilimli fay1 ise olasılı aktif bir faydır (Emre vd., 1999).

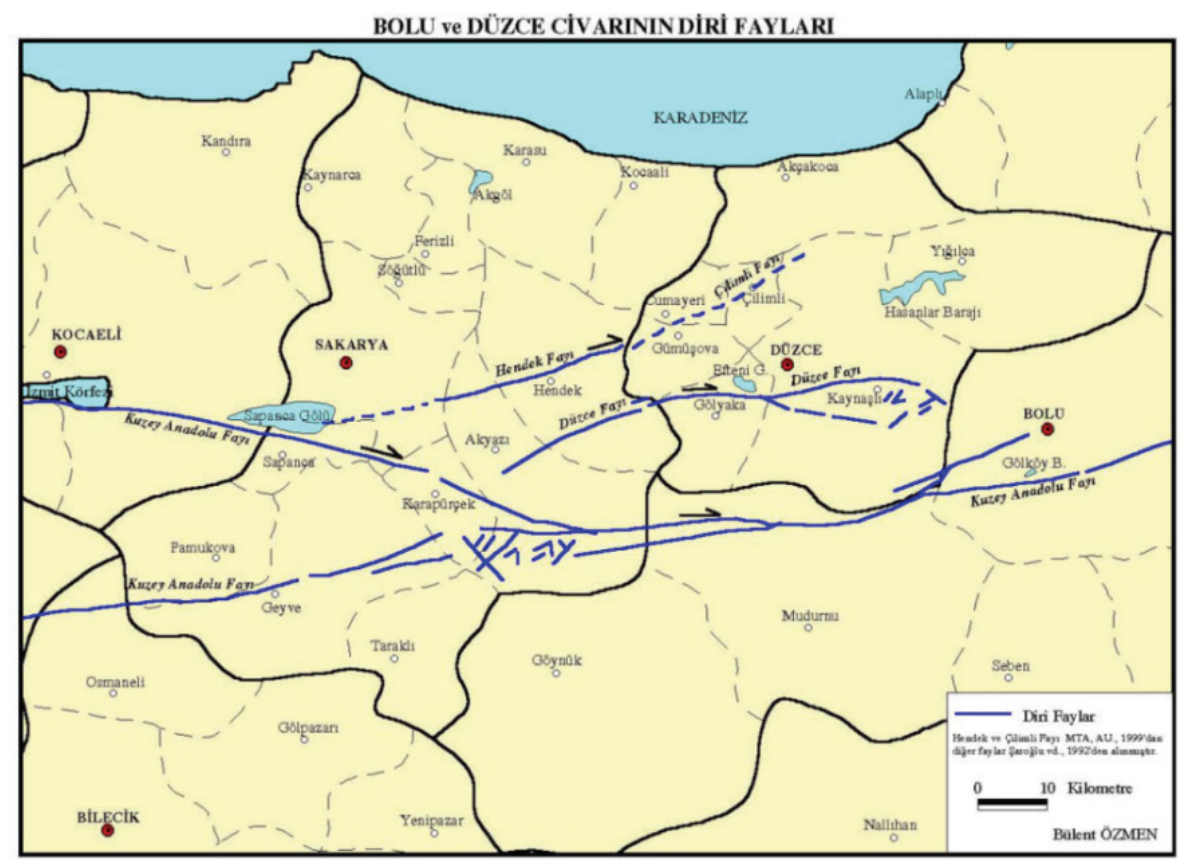

Şekil 3. Düzce ve yakın civarındaki diri faylar (Özmen, 2000'den alınmıştır).

Figure 3. Active faults of Duzce and its vicinity (After Özmen, 2000). 
Akın

Düzce Fay1: Akyazı-Kaynaşlı arasında uzanan ve Efteni gölünün güneybatısında çatallanan yaklaşık D-B uzantılı ve uzunluğu 70 km olan bu fay sağ yönlü doğrultu atımlı aktif bir faydır (Şaroğlu vd., 1987; 1992).

Hendek Fayı: Düzce havzasının batısında Sapanca Gölü-Hendek-Cumayeri arasında uzanan KD-GB uzanımlı fay Hendek fayı olarak isimlendirilmiştir (Emre vd., 1999). Sağ yönlü doğrultu atımlı fay yaklaşı $50 \mathrm{~km}$ uzunluğundadır. Hendek-Cumayeri arasında kalan 25 km'lik bölümünde morfolojik olarak çok belirgin olan bu fay Adapazarı ovasında olasılı olarak haritalanmıştır (Emre vd., 1999).
Çilimli fayı: Düzce havzasının kuzeyinde Cumayeri-Konuralp arasında uzanan ve yaklaşı $1 \mathrm{k}$ uzunluğu $13 \mathrm{~km}$ olan bir faydır. Fayın niteliği ve aktivesine ilişkin ayrıntılı veri toplanamamasına rağmen arazide fay boyunca uzamış şekilli basınç sırtlarının gözlenmesi ve fay çizgisi boyunca çok sayıda kaynak dizilimi gözlenmiş olması sebebi ile olasılı aktif fay olarak değerlendirilmiştir (Emre vd., 1999).

İnceleme alanı ve yakın çevresine yönelik aletsel ve tarihsel dönemlerde meydana gelen depremler Şekil 5 ve Çizelge 1'de verilmiştir (Ergin vd., 1967; Özmen, 2000).

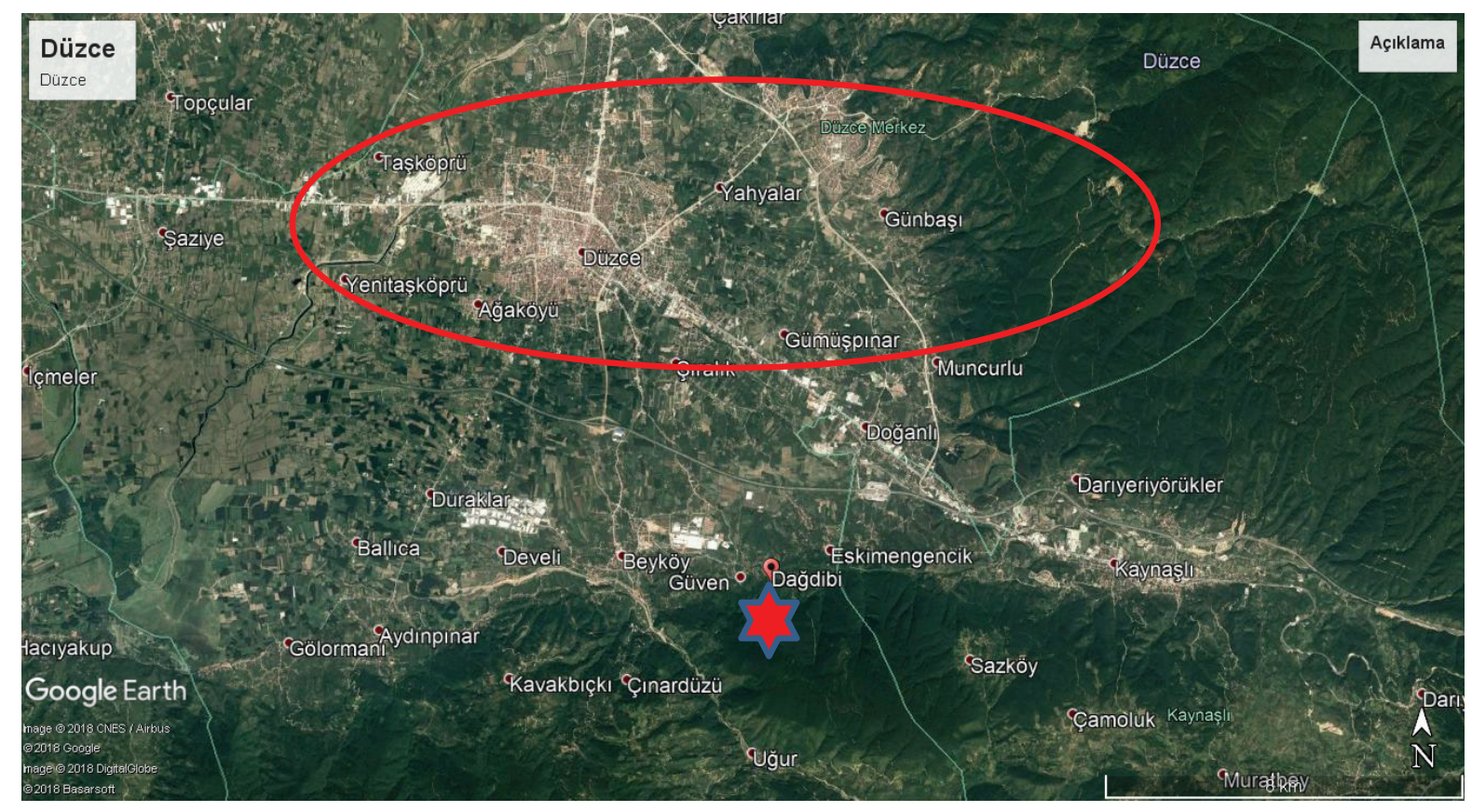

Şekil 4. Kuzey Anadolu Fay Zonu üzerinde meydana gelen 12 Kasım 1999 depremi merkez üssü.

Figure 4. Epicenter of 12 November 1999 earthquake on the North Anatolian Fault Zone. 


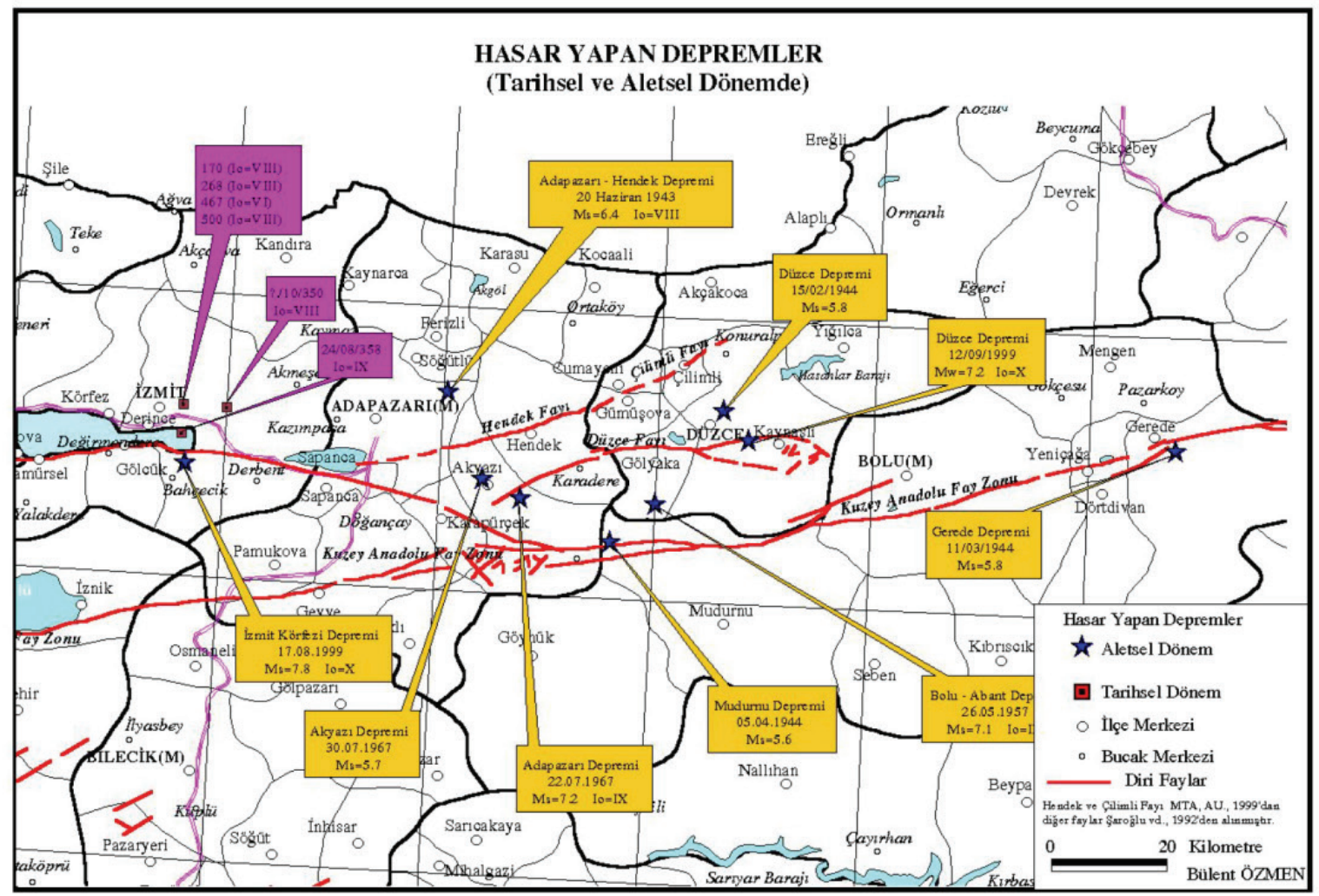

Şekil 5. Tarihsel ve aletsel dönemde hasar yapan depremler (Özmen, 2000'den alınmıştır).

Figure 5. Devastating earthquakes in historical and instrumental time periods (After Özmen, 2000).

Düzce ovası Kuzey Anadolu Fay Zonundaki yer hareketlerinin etkisiyle oluşmuş genç bir çöküntü havzasıdır (Tatar, 2003). Kabaca kare biçimli olup doğu-batı boyutu $23 \mathrm{~km}$, kuzeygüney boyutu ise $20 \mathrm{~km}$ kadardır. Düzce depremi kırığına 5-10 km uzaklıkta olan kent, Düzce ovasını oluşturan gevşek alüvyon zeminler üzerinde yer almaktadır. Bu deprem sırasında gözlenen hasarlar kent içerisinde belirli alanlarda yoğunlaşmıştır. Bu yoğunluk zonları olasılıkla yeraltı suyu seviyesi yüksek olan eski akarsu kanal dolgularının oluşturduğu zeminlerdir. Düzce'deki hasar dağılımında yerel zemin özelliklerinin belirleyici etkisi olmuştur. Ateş vd. (2013) tarafindan yapılan Düzce ili için sıvılaşma koşullarının etkisi ve zemin büyütme özellikleri ile yapıların etkileşimi gibi çalışmalara rastlanılmaktadır. Düzce, Kuvarterner alüvyon çökellerin oldukça geniş yayılım sunduğu bir yerleşim yeridir (Özaslan vd., 2001). 
Akın

Çizelge 1. Aletsel ve tarihsel dönemlerde meydana gelen büyüklüğü 5'ten fazla olan depremler (Kadirioğlu vd., 2014).

Table 1. Earthquakes with a magnitude greater than 5 in historical and instrumental time periods (Kadirioglu et al., 2014).

\begin{tabular}{lcccccc}
\hline $\begin{array}{c}\text { Yerleşim } \\
\text { yerleri }\end{array}$ & Tarih & $\begin{array}{c}\text { Deprem } \\
\text { merkezi }\end{array}$ & Mw & $\begin{array}{c}\text { Toplam } \\
\text { yapısal hasar }\end{array}$ & Ölü sayısı & $\begin{array}{c}\text { Yaralanma } \\
\text { sayıs1 }\end{array}$ \\
\hline Mürefte & 09.08 .1912 & $40.60-27.20$ & 7.3 & 5540 & 216 & 466 \\
Hendek & 20.06 .1943 & $40.85-30.51$ & 6.6 & Yok & 336 & Yok \\
Gerede & 01.02 .1944 & $41.41-32.69$ & 7.2 & 20865 & 3959 & Yok \\
Düzce & 10.02 .1944 & $41.00-32.30$ & 5.4 & 900 & Yok & Yok \\
Mudurnu & 05.04 .1944 & $40.84-31.12$ & 5.6 & 900 & 30 & Yok \\
Yenice & 18.03 .1953 & $39.99-27.36$ & 7.4 & 9670 & 265 & 336 \\
Abant & 26.05 .1957 & $40.60-31.20$ & 7.1 & 4201 & 52 & 100 \\
Çınarcık & 18.09 .1963 & $40.77-29.12$ & 6.3 & 230 & 1 & 26 \\
Adapazarı & 22.07 .1967 & $40.60-30.89$ & 7.2 & 5569 & 89 & 235 \\
Gelibolu & 27.03 .1975 & $40.45-26.12$ & 6.4 & 980 & 7 & Yok \\
Gölcük & 13.09 .1999 & $40.80-30.03$ & 5.7 & Yok & Yok & Bilinmiyor \\
Düzce & 12.11 .1999 & $40.79-31.21$ & 7.2 & 15389 & 845 & 4948 \\
Bolu & 17.11 .1999 & $40.83-31.51$ & 5.0 & Yok & Yok & Yok \\
Bolu & 22.03 .2000 & $40.94-31.58$ & 5.4 & Yok & Yok & Yok \\
Ylğılca & 26.08 .2001 & $40.93-31.53$ & 5.1 & Yok & Yok & Yok \\
\hline
\end{tabular}

SAHA VE LABORATUVAR ÇALIŞMALARI

Çalışma alanında geniş yayılım gösteren Kuvaterner alüvyon zeminler, çakıllı, kumlu, siltli, killi, az bloklu, yanal ve düşey geçişli seviyeler birbirleri içinde merceklenmeli, kamalanmalı, gevşek ve tutturulmamış nitelikteki bir özelliğe sahiptir. İnceleme alanında yapılan sondajlardan alınan örneklerde genelde üstten alta doğru az kumlu siltli kil, siltli kil kum, siltli iri kumlu kil, çakıl, iri kum çakı1 serileri gözlenmektedir (Öztürk, 2016). Düzce Merkez Belediyesi İmar Planına esas jeolojikjeoteknik etüt kapsamında Düzce'deki yerel zemin koşullarının ve yeraltısuyu durumunun belirlenmesi amacıyla yapılmış 40 adet jeoteknik sondaja ait veriler dikkate alınarak tüm analizler ve değerlendirmeler yapılmıştır (Akbaşl1, 2008).
Çalışma alanında derinlikleri 10.00-15.00 m arasında değişen toplam $591 \mathrm{~m} 40$ adet jeoteknik sondajyapılmıştır. Bu sondajyerlerinindağılımına Şekil 7'de yer alan haritalarda yer verilmiştir. Etkin derinliği açısından zemin sıvılaşmasının en az 20 m'ye kadar değerlendirilmesi yaygın bir şekilde kabul edilmektedir. Ancak, bu çalışmada kullanılan jeoteknik sondajların en fazla $15 \mathrm{~m}$ derinliğe ulaşması bu yönüyle bir sınırlama olmakla birlikte derinliğe bağlı olarak sıvılaşmanın yüzeydeki etkilerinin de azalacağı dikkate alınarak tüm değerlendirmeler mevcut jeoteknik sondaj verileri dikkate alınarak yapılmıştır. Jeoteknik sondajlarda geçilen birimler Kuvaterner yaşlı alüvyonal çökeller ve Yığılca formasyonuna ait birimler olup, genel olarak siltli kil, killi kumlu silt, çakı1lı siltli kum 
seviyeleri geçilmiştir. Jeoteknik sondajlarda her 1.50 m'de bir standart penetrasyon deneyi (SPT) uygulanmış ve zemin örnekleri alınmıştır (Akbaşl1, 2008). İnceleme alanındaki bu jeoteknik sondajlardan 22'sinde yeraltısuyuna rastlanmış olup, yeraltısuyu seviyeleri 1,00 ile 9,50 $\mathrm{m}$ arasında değişmektedir.

\section{FARKLI DEPREM SENARYOLARINA GÖRE SIVILAŞMA POTANSIYELININ DEĞERLENDİRILMESİ}

Zemin sıvılaşması değerlendirmelerinde sadece ait seviye olduğu için anlamlılık sunan sıvılaşmaya karşı güvenlik katsayısının belirlenmesinin yanısıra, yüzeyden derine doğru tüm profil için anlamlandırılan yaklaşımlar da bulunmaktadır. İlk defa Iwasaki vd. (1982) tarafından yüzeyden derine doğru 20 m'lik zemin profili için önerilen Sıvılaşma Potansiyeli İndeksi (LPI) kavramı, Sonmez (2003) tarafindan yapılan çalışmayla da LPI'nın genel yaklaşımı korunarak sıvılaşma potansiyeli sınıflaması yeniden düzenlenmiştir. Sonmez ve Gokceoglu (2005) ise sıvılaşmaya karşı güvelik katsayısı değerine bağlı olarak sıvılaşma olasılığına ilişkin Juang vd. (2003) tarafından önerilen ilişkiyi ve ayrica Chen and Juang (2000) tarafindan önerilen sıvilaşma olasılığ sinıflamasını birlikte dikkate alarak, yine Iwasaki vd. (1982) tarafından önerilen genel yaklaşım temelinde Sıvılaşma Şiddeti İndeksi (LSI) eşitliğini ve ilgili sınıflamasını önermişlerdir.

Bu çalışma kapsamında, Iwasaki vd. (1982) tarafından önerilen Sıvılaşma Potansiyeli İndeksi (LPI) ve Sonmez ve Gokceoglu (2005) tarafından önerilen Sıvılaşma Şiddeti İndeksi (LSI) yaklaşımları ve ilgili sınıflamaları dikkate alınarak, mevcut verilerden itibaren inceleme alanının sıvılaşma potansiyeli değerlendirmesine yönelik sıvılaşma haritaları farklı deprem senaryoları için üretilmiştir. İnceleme alanında dikkate alınan farklı deprem senaryolarına ait parametreler Çizelge 2'de özetlenmiştir.

Çizelge 2. Çalışmada dikkate alınan olası deprem senaryoları.

Table 2. Possible earthquake scenarios considered in this study.

\begin{tabular}{|c|c|c|c|}
\hline Senaryolar & $\begin{array}{l}\text { Deprem büyüklüğü } \\
\mathrm{M}_{\mathrm{w}}\end{array}$ & $\begin{array}{l}\text { Maksimum ivme } \\
\text { değeri, PGA (g) }\end{array}$ & Açıklama \\
\hline 1 & 7.5 & 0.5 & $\begin{array}{c}\text { Düzce ve yakın çevresinin depremselliği için yeni } \\
\text { deprem yönetmeliği temelinde olası deprem senaryosu }\end{array}$ \\
\hline 2 & 7.2 & 0.8 & $\begin{array}{c}1999 \text { Düzce depremi Bolu İstasyon kayıtları dikkate } \\
\text { alınarak (Çeken, 2000) }\end{array}$ \\
\hline 3 & 7.2 & 0.4 & $\begin{array}{c}1999 \text { Kocaeli depremi Sakarya İstasyonu kayıtları } \\
\text { dikkate alınarak (Erdik, 2000) }\end{array}$ \\
\hline
\end{tabular}


Iwasaki vd. (1982) tarafindan belirtilen çalışmada sıvılaşabilir tabakaların kalınlığı ve ayrıca güvenlik katsayıları dikkate alınarak aşağıda belirtilen eşitlikler yardımıyla hesaplamalar yapılmaktadır.

$$
\begin{aligned}
& L P I=\int_{0}^{20} F(z) W(z) d z \\
& F(z)=1-F S(F S<1.0 \text { için }) \\
& F(z)=0(F S \geq 1.0 \text { için }) \\
& W(z)=10-0.5 z(z \leq 20 m \text { için }) \\
& W(z)=0(z>20 m \text { için })
\end{aligned}
$$

LPI ile belirtilen sıvılaşma potansiyeli indeksi yüzeyden $20 \mathrm{~m}$ derinliğe kadar güvenlik katsayısı (F) ve ağırlık sabiti (W) değerlerindeki değişimlere göre derinlikle değişen değerlere bağlı olarak Eşitlik (1) yardımıyla hesaplanmaktadır. LSI'ya göre ise $\mathrm{P}_{\mathrm{L}}$ yani sıvılaşma olasılığ kadar olan sıvılaşabilen seviyelerin derinliğe bağlı olarak toplam sıvılaşma potansiyeli ortaya konmaktadır. Aşağıda belirtilen eşitlik yardımı ile sıvılaşma şiddet indeksi hesaplanmaktadır.

$$
\begin{aligned}
& L_{s}=\int_{0}^{20} P_{L}(z) W(z) d z \\
& P_{L}(z)=\frac{1}{1+\left(\frac{F_{L}}{0.96}\right)^{4.5}}\left(F_{L} \leq 1.411 \text { için }\right) \\
& P_{L}(z)=0\left(F_{L}>1.411 \text { için }\right)
\end{aligned}
$$

Sıvılaşma analizlerine yönelik olarak yerleşim yeri için elde edilen ayrıntılı saha ve laboratuvar çalışmalarına ait verilerin yanı sıra, 2019'da uygulamaya geçecek olan ülkemize ait güncel Deprem Yönetmeliği (Resmi Gazete, 2018) de dikkate alınarak seçilen farklı deprem senaryoları için Sıvılaşma Potansiyeli İndeksi ve Sıvılaşma Şiddeti İndeksi değerleri tüm jeoteknik sondaj lokasyonları için hesaplanmıştır. Deprem senaryolarına karar verilmeden önce, yeni deprem yönetmeliğinin web tabanlı uygulaması kullanılarak deprem görülme olasılığının \%50 değeri için, olası en büyük yatay yer ivmesinin (Peak Ground Acceleration, PGA) 475, 72 ve 43 gal değerleri için Düzce ve yakın çevresini de içerecek alanda yatay ivme dağılım haritaları değerlendirilmiştir (Şekil 6). Bu değerlendirme ile inceleme alanı ve çevresi için en büyük yatay yer ivmesinin güncel deprem yönetmeliğine göre $\quad 0.5 \mathrm{~g}$ düzeylerinde gelişebileceği öngörülebilmektedir. Bununla birlikte, 17 Ağustos ve 12 Kasım 1999 Kocaeli ve Düzce depremlerinin büyüklükleri 7.5 ve 7.2 ve yine ölçülen $0.8 \mathrm{~g}$ en büyük yatay yer ivmesi değeri de dikkate alınarak üç farklı deprem senaryosu seçilmiştir (Çizelge 2).

Her üç senaryo deprem için ayrı ayrı olmak üzere, jeoteknik sondajlara ait LPI ve LSI değerleri hesaplanmış ve Ters Mesafe Ağırlık (IDW) yöntemi kullanılarak CBS ortamında, Iwasaki (1982) ve Sonmez ve Gokceoglu (2005) tarafından sırasıyla LPI ve LSI için önerdiği sınıf sınır değerleri dikkate alınarak sıvılaşma haritaları hazırlanmıştır (Şekil 7). 

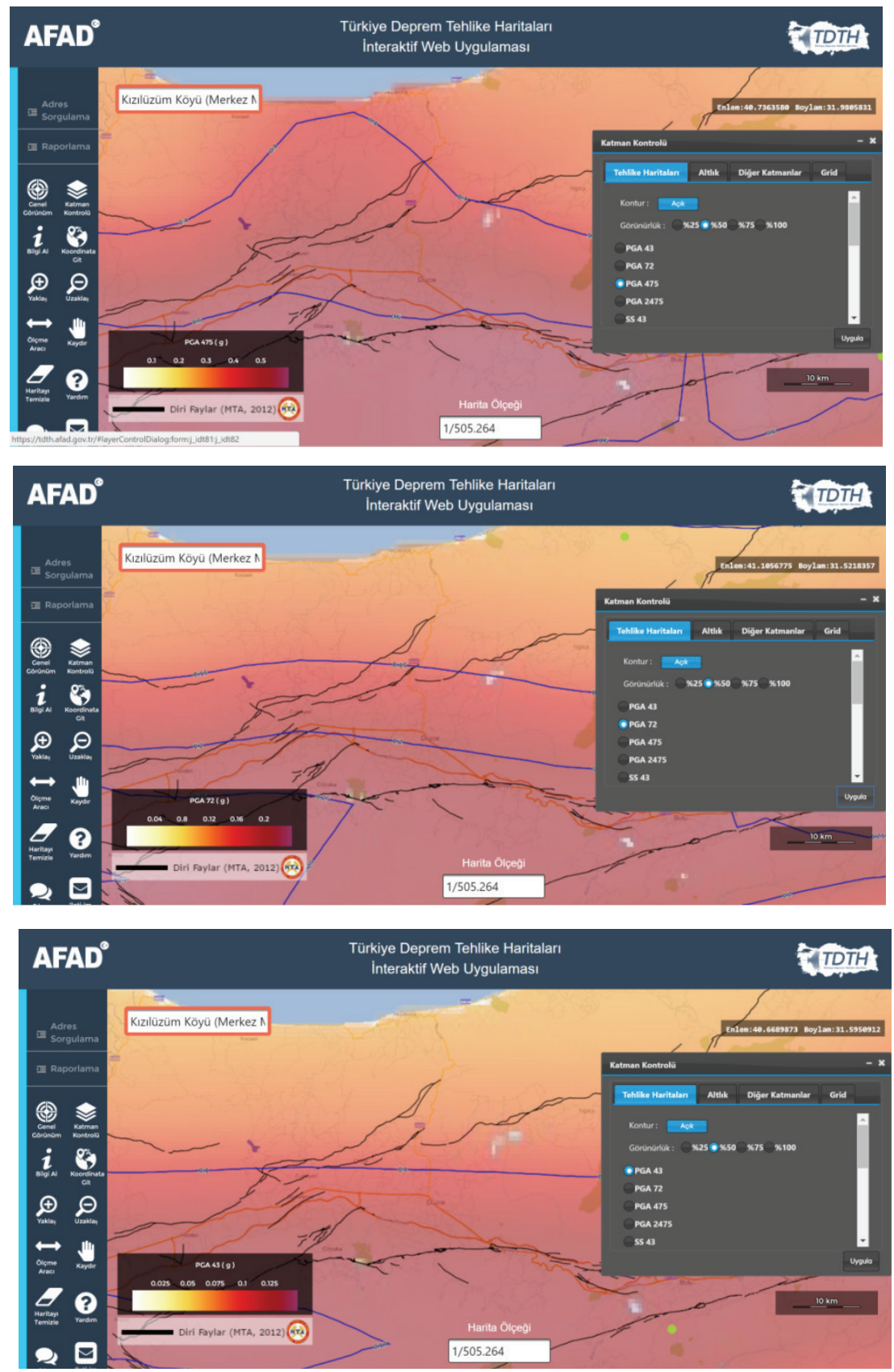

Şekil 6. İnteraktif web uygulamasında farklı aşılma ihtimalleri için maksimum yer ivmesi değerlerinin dağılımı (https://tdth.afad.gov.tr/).

Figure 6. Distribution of maximum ground acceleration values for different exceedance probability in interactive web application (https://tdth.afad.gov.tr/). 
Akın

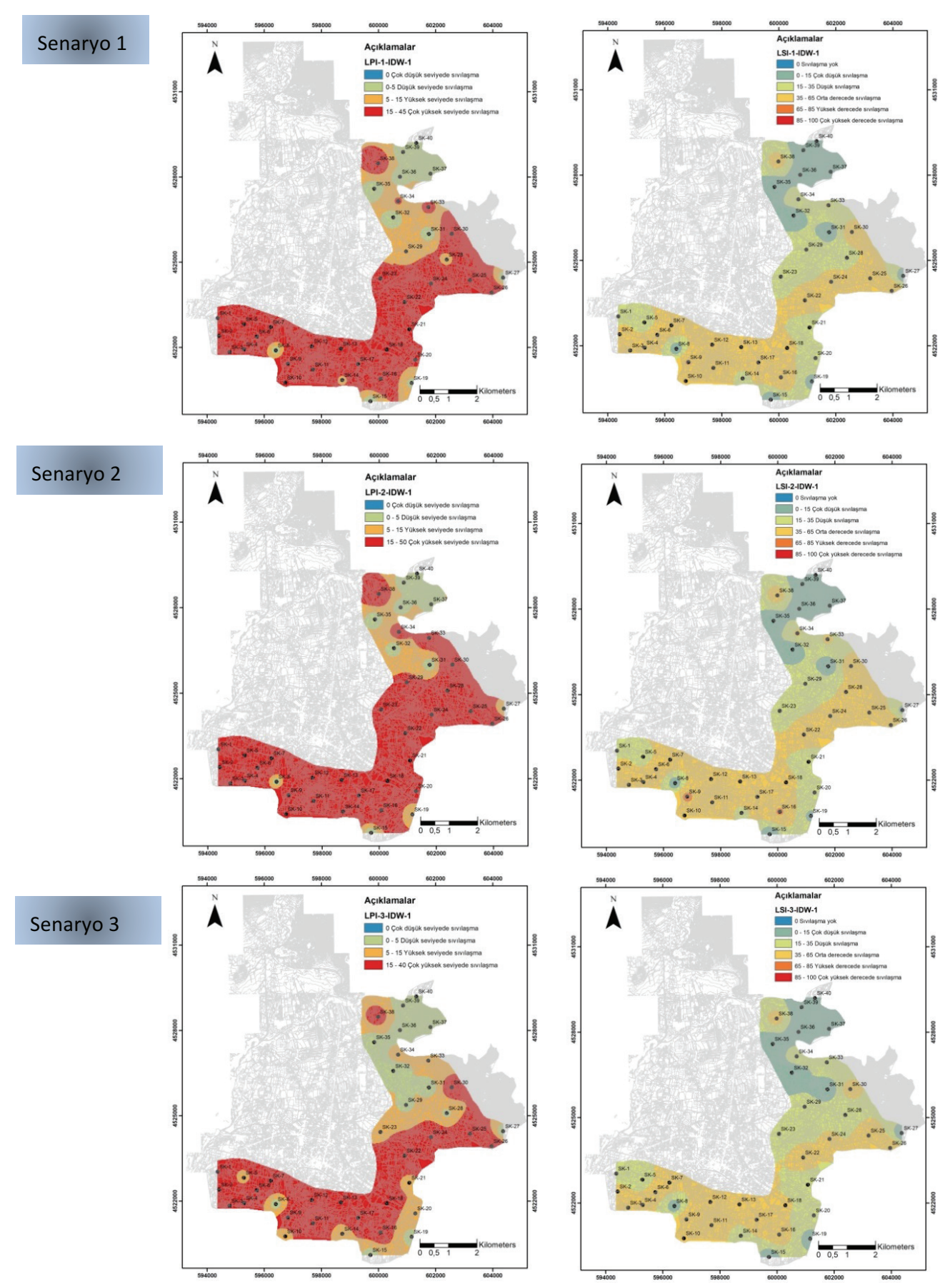

Şekil 7. Farklı deprem senaryoları için LPI (Iwasaki vd.,1982) ve LSI (Sonmez ve Gokceoglu, 2005) yöntemleriyle üretilen sıvılaşma haritalarının karşılaştırılması.

Figure 7. Comparison of LPI (Iwasaki et al., 1982) and LSI (Sonmez and Gokceoglu, 2005) based liquefaction maps with respect to different earthquake scenarios. 
Genel olarak deprem senaryosu 1 ve 2 için benzer LPI ve LSI sınıflandırılmış haritaları elde edilmiştir. Buna karşın deprem senaryosu 3 için nispeten daha tutucu sınıflandırılmış haritalar elde edilmiştir. $\mathrm{Bu}$ durum, farklı deprem senaryoları için ön görülen moment büyüklüğü $\left(M_{w}\right)$ ve en büyük yatay yer ivmesi $\left(a_{\max }\right)$ değişimleri ile kontrol edilmektedir. Sonuç olarak sıvılaşma haritalaması yapılan alanın güney kesimlerinde olası deprem senaryolarının yaşanması durumunda sıvılaşma olayının yüzey etkilerinin daha fazla gözlenebileceği söylenebilir. Önceki bölümlerde sunulduğu üzere sahadaki jeoteknik sondaj derinlikleri genel olarak en fazla 15 m'ye kadar ulaşmaktadır. Buna karşın LPI ve LSI hesaplamalarında $20 \mathrm{~m}$ derinliğe kadar uzanan profilin değerlendirilmesi gerekmektedir. Bu nedenle, 20 m derinliğe kadar değerlendirmelerin yapılması durumunda ön değerlendirme amacıyla bu çalışmada hazırlanan sıvılaşma haritalarıyla karşılaştırıldığında derinlerdeki zemin özelliklerine bağlı olarak nispeten daha yüksek LPI ve LSI değerlerinin de elde edilmesi olasıdır.

Sıvılaşmanın yüzey etkilerinin göreceli değerlendirilmesinde kullanılabilen LPI ve LSI diğerleri teorik olarak 0 ile 100 arasında değişebilmektedir. Iwasaki vd. (1982) tarafindan LPI'nın sınıflama sınır değerleri "çok düşük", "düşük", "yüksek" ve "çok yüksek" sınıfları için sirasıly $0,0-5,5-15$ ve 15 'ten büyük arasında önerilmekle birlikte, bu sınırların farklı değerlere sahip olabileceği yönünde bazı güncel çalışmalar da mevcuttur. Diğer taraftan LPI'nın 15 'ten büyük geniş bir aralığ 1 “çok yüksek" sıvılaşma potansiyeli sınıfina dahil edilmektedir. Sıvılaşma olasılığı temelli LSI'ya göre önerilen sıvılaşma şiddeti sınıflamasında “yok”, “çok düşük”, "düşük”, “orta”, “yüksek” ve "çok yüksek" sınıflarının sınır değerleri ise $0,0-15,15-35,35-65,65-85$ ve $85-100$ olarak önerilmektedir. Bu nedenle, LPI yöntemini temel alan sınıflamada "çok yüksek" sınıfında geniş bir alan belirlenirken, bu alanların LSI yöntemini dikkate alan sinıflamada genellikle "orta" sınıfına sahip olduğu görülmektedir. Ayrıca, bu aşamada LPI'ya göre Iwasaki vd. (1982) tarafindan önerilen sinıflamada "orta" sinıfinın da tanımlanmadığı dikkate alınmalıdır.

\section{GENEL DEĞERLENDİRME}

Düzce ovası 5 milyon yıl kadar önce Kuzey Anadolu fay sistemine bağlı yerkabuğu hareketleriyle meydana gelmiş, derin ve etrafi dağlarla çevrili geniş bir birikim havzasıdır. Oluşumundan bu yana çevredeki dağlardan ovaya yerleşmiş bulunan akarsuların taşıyıp getirdiği alüvyonlarla ve kolüvyonlarla dolmuştur. Bunlara ek olarak ovada oluşmuş geçmişte daha büyük olduğu anlaşılan Efteni gölünün çökeltileri de havzanın dolmasına katkıda bulunmuştur. Ovadaki Kuvaterner birikintilerinin kalınlığı orta kesimlerde 260 m'yi bulmaktadır. Ovayı dolduran bu gevşek kalın tortuların içinde yeraltı su seviyesi oldukça sığdır. Yeraltı suyu tablasının derinliği bazı kesimlerde 0,5 m'ye kadar düşmektedir. Genelde 2.5-3.3 m arasındadır. Tamamen alüvyon zemin üzerinde kurulu il merkezinde 1965 tarihli imar planı gereği en fazla üç katlı yapılaşmaya izin verilirken, 1970'li yılların başlarından itibaren özellikle şehrin merkezi kısımlarında, çoğunluğu 5 ve 6 katlı yapılar hızla artmıştır. Bazı durumlarda kat sayısı eklemelerle 6'nın da üzerine çıkarılmıştır. 1999 deprem felaketlerinde bu çok katlı binaların neredeyse tamamı çökmüş veya ağır hasara uğradığından yıkılarak ortadan kaldırılmıştır (Tatar, 2003). Düzce için Başbakanlık Kriz Yönetim Merkezi'nin açıklamasına göre, ölü sayıs1 845, yaralı sayıs1 4948 olarak belirtilmiştir. Depremde hasar gören 
Akın

ve derhal yık1lması gereken bina sayıs1 3395, yıkık ya da ağır hasarlı ev sayısı 12939, iş yeri sayısı ise 2450 'dir. İlgili hasar dağılım oranı Şekil 8'de verilmiştir (Özmen, 2000).

\section{SONUÇLAR}

Sonuç olarak, bu çalışma kapsamında Düzce ilinde yeni yapılaşmaların arttığı

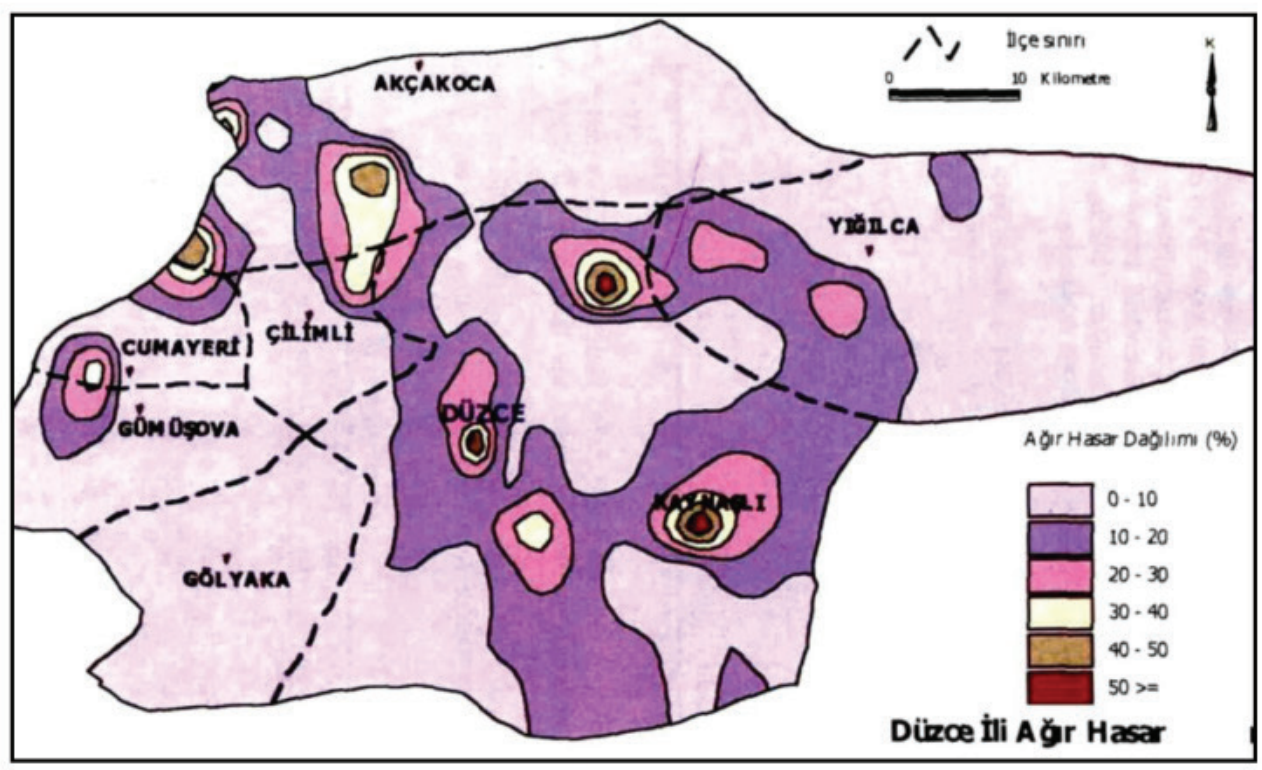

Şekil 8. 1999 Depreminin Düzce ilinde oluşturduğu ağır hasar dağılımı (Özmen, 2000'den alınmıştır).

Figure 8. The heavy damage distribution of the 1999 earthquake in Düzce province (After Özmen, 2000).

Buna göre deprem yüzey kırığına 5-10 km uzaklıkta olan kent merkezi, Düzce ovasını oluşturan gevşek alüvyon zemin üzerindedir. Hasar, kent içerisinde belirli alanlarda yoğunlaşmıştır. $\mathrm{Bu}$ yoğunluk zonları olasılıkla yeraltısuyu seviyesi yüksek olan eski akarsu kanal dolgularının oluşturduğu zeminlerdir. Düzce'deki hasarın yerel zemin özelliklerinin belirleyici etkisi olmuştur (Ateş vd., 2013). Düzce'de deprem sonrası sıvılaşmaların yüzeye etkisine yönelik herhangi bir belirti gözlenmemesine karşın, bazı binalarda toplam veya kısmi sıvılaşmaya bağlı olarak oturmalar olduğu gözlenmiştir (Erdik, 2001). güney ve güneydoğu kesimlerinde sıvılaşma potansiyelinin yüksek-çok yüksek olduğu belirlenmiştir. Bunun yanı sıra, inceleme alanının kuzeyine doğru gidildikçe sıvılaşma potansiyeli azalsa da, LPI ve LSI yöntemlerine göre bu bölgelerin bazı kesimlerinde halen düşük-orta sıvılaşma potansiyeli olduğu görülmektedir. Kuzey Anadolu Fay Zonu gibi büyük depremler üretebilecek önemli bir sismik kaynak içinde yer alan Düzce ili için gerek parsel ve gerekse planlama bazında farklı deprem senaryolarının dikkate alınması gerekmektedir. Yüksek sıvılaşma riski olan alanlarda yapılacak yapılaşmalarda jeoteknik parametreler ayrıntılı olarak belirlenmeli ve özellikle sıvılaşmaya 
yönelik analizler detaylı ve gerçekçi bir şekilde yapılmalıdır. Analizler sonucunda sıvılaşma potansiyeli yüksek olan alanlarda uygun zemin iyileştirme yöntemlerinin uygulanması sağlanmalıdır. Diğer bir ifadeyle zemin-yap1 etkileşiminde sıvılaşma ve sıvılaşmaya bağlı yüzey deformasyonları dikkate alınmalıdır.

Çalışmada LSI yöntemine göre hazırlanan haritalarda farklı deprem senaryolarındaki deprem büyüklüğü ve ivme değerlerine rağmen çok farklılık göstermemesi dikkatle değerlendirilmelidir. Özellikle farklı deprem senaryolar1 için ön görülen moment büyüklüğü $\left(\mathrm{M}_{\mathrm{w}}\right)$ ve en büyük yatay yer ivmesi $\left(\mathrm{a}_{\max }\right)$ değişimleri oluşturulan haritalarda yerel olarak değişikliklere yol açmıştır. $\mathrm{Bu}$ değişiklikler özellikle yatay yer ivmesi değerlerine oldukça hassas olduğu tespit edilmiştir ve farklı deprem senaryolarına göre özellikle LPI yönteminden elde edilen sonuçların değişkenlik gösterdiği gözlenmiştir. $\mathrm{Bu}$ nedenle sıvılaşma potansiyelinin değerlendirilmesine yönelik farklı yöntemlerden elde edilen sonuçlar, yapılacak detay analizlerle sıvılaşma sonrası meydana gelebilecek yüzey deformasyonlarının (oturma, yanal yayılma) boyutu açısından da incelenmeli ve yerel ölçekte sıvılaşma analizi güvenli tarafta kalınması bakımından zemin büyütme olasılığ 1 da dikkate alınarak yatay yer ivmesi değerlerine dayalı olarak sıvılaşma analizleri ve modelleri gerçekleştirilmelidir.

\section{TEŞEKKÜR}

İller Bankası'ndan Sayın Jeoloji Yük. Müh. Tahsin Metin'e ve NEVHÜ'den Dr. Öğr. Üyesi Ahmet Orhan'a teşekkürlerimi sunarım. Ayrıca, yazar makalenin geliştirilmesindeki değerli katkılarından dolayı editör Prof. Dr. Tamer TOPAL ve hakemlere teşekkür eder.

\section{KAYNAKLAR}

Akbaşlı Mühendislik Sondaj İnşaat Madencilik Taahhüt Ticaret Limited Şirketi. Aralık-2008, Düzce (Merkez) Belediyesi-İmar Planına Esas Jeolojik-Jeoteknik Etüt Raporu.

Akin M.K., Topal T., Kramer S.L., 2013. A newly developed seismic microzonation model of Erbaa (Tokat, Turkey) located on seismically active eastern segment of the north Anatolian fault zone (NAFZ). Natural Hazards. 65:1411-1442.

Andrus, R.D., Stokoe II, K.H., 1997. Liquefaction Resistance Based on Shear Wave Velocity. NCEER Workshop on Evaluation of Liquefaction Resistance of Soils, Technical Report NCEER-97-0022, T.L.Youd and I.M. Idriss, (Eds.), Held (1996), Salt Lake City, UT, Buffalo, NY, 89-128.

Andrus, R. D., Stokoe, K. H., 2000. Liquefaction Resistance of Soils from Shear-Wave Velocity. Journal of Geotechnical and Geoenvironmental Engineering, Vol. 126, No. 11, pp. 1015-1025.

Ateş, A., Toprak, B., Yeşil, B., 2013. Düzce ilinde yapı hasarlarının zemin büyütme özellikleri ve yap1 rezonans uyumu ile ilgisinin araştırılması. İleri Teknoloji Bilimleri Dergisi Cilt 2, Say1 3, 76-86.

Çetin, K. O., 2000. Reliability-Based Assessment of Seismic Soil Liquefaction Initiation Hazard, $\mathrm{Ph}$.D. dissertation, Univ. of California, Berkeley (unpublished).

Çetin K.O., Seed R.B., Der Kiureghian A., Tokimatsu K., Harder L.F. Jr., Kayen R.E., Moss R.E.S., 2004. Standard penetration test-based probabilistic and deterministic assessment of seismic soil liquefaction potential. Journal of Geotechnical and Geoenvironmental Engineering, 130(12), 1314-1340.

Çeken, U., 2000. Türkiye'nin kuvvetli yer hareketi kayıt şebekesi ve 12 Kasım Düzce depreminin ivmesi. 12 Kasım 1999 Düzce Depremi Raporu. Bayındırlık ve İskan Bakanlığı, Afet İşleri Genel Müdürlüğü DAD, Editörler: B. Özmen ve G. Bağcı, 224 s., Ankara. 
Akın

Day, R., 2002. Geotechnical Earthquake Engineering Handbook. McGraw Hill Handbook. pp. 700.

Demirtaş, R., Erkmen, C., Yaman, M., 2000. 12 Kasım 1999 Düzce Depremi: Yüzey Kırık Geometrisi, Atım Miktarı Dağılımı ve Gelecek Deprem Potansiyeli s:61-99, 12 Kasım Düzce Depremi Raporu (Editör: Bülent Özmen ve Günruh Bağc1), Deprem Araştırma Dairesi, Afet İşleri Genel Müdürlüğü, Ankara.

Emre, Ö. vd. (MTA), Varol, B. vd. (A.Ü.), 1999. 17 Ağustos 1999 Depremi Sonrası Düzce (Bolu) İlçesi Alternatif Yerleşim Alanlarının Jeolojik İncelemesi. TÜBİTAK (MTA Genel Müdürlüğü ve A.Ü. Ortak Araştırma Projesi).

Emre, Ö., Özalp, S., Doğan, A., Özaksoy, V., Yıldırım C., Göktaş F., 2005. Düzce ve çevresinin diri fayları ve deprem potansiyelleri. MTA Jeoloji Etüdleri Dairesi Rapor No: 10754.

Ergin, K., Güçlü Ü., Uz, Z., 1967. Türkiye ve civarının deprem kataloğu (M.S. 11 1964): İTÜ Arz Fiziği Enst. Yay. 28, $74 \mathrm{~s}$.

Erdik, M., 2000. Report on 1999 Kocaeli and Düzce (Turkey) Earthquakes. Boğaziçi University Departmant of Earthquake Engineering, İstanbul.

Erdik, M., 2001. Report on 1999 Kocaeli And Düzce (Turkey) Earthquakes. Structural Control for Civil and Infrastructure Engineering, pp. 149186.

Erkman, H.K., 1949, 23.7.1949. Karaburun-Düzce zelzelesi. İstanbul Kandilli Rasathanesi, Jeofizik, No:1.

ESRI, 2009. ArcGIS Desktop: Release 9.3. Redlands, CA: Environmental Systems Research Institute.

Idriss, I. M., R. W. Boulanger, 2006. Semi Empirical Procedures for Evaluating Liquefaction Potential During Earthquakes. Soil Dynamics Earthquake Engineering, Vol. 26, Iss. 2-4, pp. 115-130.

Iwasaki, T., Arakawa, T., Tokida, K., 1982. Simplified procedures for assessing soil liquefaction during earthquakes. Proceedings of the Conference on Soil Dynamics and Earthquake Engineering, Southampton, UK, pp. 925-939.
Juang, C.H., H., Yuan, D.H. Lee, P.S. Lin, 2003. Simplified Cone Penetration Test-based Method for Evaluating Liquefaction Resistance of Soils. Journal of Geotechnical and Geoenvironmental Engineering, Vol. 129, No. 1, pp. 66-80.

Kadirioğlu, F. T., Kartal, R. F., Kılıç, T., Kalafat, D., Duman, T. Y., Özalp, S., Emre, Ö., 2014. An Improved Earthquake Catalogue (M ? 4.0) For Turkey And Near Surrounding (1900-2012). 2nd European Conference on Earthquake Engineering and Seismology, İstanbul Aug. 2529, 2014.Page:411-422 (Proceedings Book).

Kramer, S.L., 1996. Geotechnical Earthquake Engineering. Prentice Hall, Englewood Cliffs, N.J., 653.

Moss, R.E.S., 2003. CPT-Based Probabilistic Assessment of Seismic Soil Liquefaction Initiation Ph.D. Dissertation, University of California, Berkeley.

Moss, R. E. S., Seed, R. B., Kayen, R. E. , Stewart, J. P., Der Kiureghian, A., Cetin, K.O., 2006. CPT-Based Probabilistic and Deterministic Assessment of in situ Seismic Soil Liquefaction Potential. Journal of Geotechnical and Geoenvironmental Engineering, 132, 8, 10321051.

NCEER. 1997. Proceedings of the NCEER Workshop on Evaluation of Liquefaction Resistance of Soils. Edited by T.L. Youd and I.M. Idriss. National Center for Earthquake Engineering Research (NCEER), N.Y. Technical Report NCEER-97-022.

Olsen, R. S., 1984. Liquefaction analysis using the cone penetrometer test. Proceedings $8^{\text {th }}$ World Conference, on Earthquake Engineering EERI, San Francisco, 247-254.

Olsen, R. S., 1997. Cyclic Liquefaction based on the Cone Penetrometer Test IN Proceedings of the NCEER Workshop on Evaluation of Liquefaction Resistance of Soils 1997. Edited by T.L. Youd and I.M. Idriss. Technical Report NCEER-97-0022, National Center for Earthquake Engineering Research, State University of New York at Buffalo, Buffalo, N.Y. 
Özaslan, M., Erşahin G., Akkahve D., Sabuncu, A., 2001. Düzce ili raporu. Başbakanlık DPT, Yayın No: 2578.

Özmen, B., 2000. Düzce-Bolu Bölgesi’nin Jeolojisi, Diri Fayları ve Hasar Yapan Depremleri s:1-14, 12 Kasım 1999 Düzce Depremi Raporu (Editör: Bülent ÖZMEN ve Günruh BAĞCI). Bayındırlık ve İskan Bakanlığı Afet İşleri Genel Müdürlüğü, Deprem Araştırma Dairesi, Ankara.

Özden, S., Tatar, O., Mesci, B. L., Koçbulut, F., Tutkun, S. Z., Doğan, B., Tüvar, O., 2000. 12 Kasım 1999 Düzce Depremi ve Bölgesel Tektonik Anlamı. Türkiye Jeoloji Bülteni, C.43, Say1:2.

Öztürk, E., 2016. 1999 Düzce Depreminde Zemin Büyütmesine Bağlı Gelişen Yapı Hasarlarının Araştırılması. Düzce Üniversitesi Bilim ve Teknoloji Dergisi, 4, 264-277.

Poulos, S.J., G. Castro, J. W. France, 1985. Liquefaction Evaluation Procedure Journal of Geotechnical Engineering, Vol. 111, No. 6, pp. 772-792.

Resmi gazete, 2018. Afet ve Acil Durum Yönetimi Başkanlığı: Türkiye Bina Deprem Yönetmeliği, Say1: 30364 (mükerrer). http://www.resmigazete. gov.tr/eskiler/2018/03/20180318M1-2.htm.

Robertson, P.K., Wride, C.E., 1998. Evaluating cyclic liquefaction potential using the cone penetration test. Canadian Geotechnical Journal, 35, 442459.

Seed, H. B., Idriss, I. M., 1971. Simplified procedure for evaluating soil liquefaction potential. Journal of Soil Mechanics and Foundations Division, ASCE 97(SM9), 1249-273.

Seed, H. B., Idriss, I. M., 1982. Ground Motions and Soil Liquefaction During Earthquakes. Earthquake Engineering Research Institute, Oakland, CA, 134 pp.

Seed, H. B., Tokimatsu, K., Harder, L. F. Jr., Chung, R., 1985. Influence of SPT procedures in soil liquefaction resistance evaluations. Journal of Geotechnical Engineering ASCE, 111(12), 1425-445.

Sonmez, H., 2003. Modification to the liquefaction potential index and liquefaction susceptibility mapping for a liquefaction-prone area (Inegol-
Turkey). Environmental Geology, 44(7), 862871 .

Sonmez, H., Gokceoglu, C., 2005. A liquefaction severity index suggested for engineering practice. Environmental Geology, Volume 48, Issue 1, pp 81-91.

Şaroğlu, F., Emre, Ö., Kuşçu, İ. 1987. Türkiye'nin diri fayları ve deprem şekilleri. MTA, Der.no:8174.

Şaroğlu, F., Emre, Ö., Kuşçu, İ., 1992. Türkiye Diri Fay Haritası. MTA, Ankara.

Şengör, A.M.C., Y1lmaz. Y., 1981. Tethyan evolution of Turkey: A plate tectonic approach. Tectonophysics, 75, 181-241.

Şimşek, O., Dalgıç, S., 1997. Düzce Ovası killerinin konsolidasyon özellikleri ve jeolojik evrim ile ilişkisi. Türkiye Jeoloji Bülteni, C:40 Sayı:22 Sayfa:29-38.

https://tdth.afad.gov.tr/ erişim tarihi : 20.12.2018.

Tatar, Y., 2003. Düzce İl Gelişme Planı. Çevre ve Mekansal Gelişme Sektörü Raporu, Düzce, 103 s.

Toprak, S., Holzer, T. L., Bennett, M. J., Tinsley, J. C., 1999. CPT- and SPT-based probabilistic assessment of liquefaction potential. Proceedings of Seventh US Japan Workshop on Earthquake Resistant Design of Lifeline Facilities and Counter-measures Against Liquefaction, T. D. O’Rourke, J. P. Bardet, and M. Hamada, eds., Report MCEER-99-0019, MCEER, NY.

Uysal, K., Herece, E., 1999. 12 Kasım 1999 Düzce depremi ön değerlendirme MTA raporu.

Yılmaz, Y., Tüysüz, O., Yiğitbaş, E., Genç, C., Şengör, C., 1997. Geology and tectonic evolution of the pontides, in A. G. Robinson, ed., Regional ind petroleum geology of the Black Sea and surrounding region, AAPG Memoir, 68, p. 183-226.

Youd, T. L., Noble, S.K., 1997. Liquefaction criteria based on statistical and probabilistic analyses. Proceedings, NCEER Workshop on Evaluation of Liquefaction Resistance of Soils, Natural Center for Earthquake Engineering Research, State Univ. of New York at Buffalo, 201-215. 
Akın

Youd T.L., Idriss I.M., Andrus R.D., Arango I., Castro

G., Christian J.T., et al., 2001. Liquefaction resistance of soils: summary report from the 1996 NCEER and 1998 NCEER/NSF workshops on evaluation of liquefaction resistance of soils. Journal of Geotechnical and Geoenvironmental Engineering 127(10): 817-833. 